\title{
Perbandingan Nilai Lendutan Jembatan Rangka Antara Box Beam Section dan Konvensional dari Kayu Kamper Sebagai Penghubung Antar Dusun
}

\author{
Handika Setya Wijaya 1) dan Andy Kristafi Arifianto 2) \\ 1) 2) Teknik Sipil, Universitas Tribbuwana Tunggadewi Malang \\ Jl. Telaga Warna, Tlogomas, Kecamatan Lowokwaru, Kota Malang \\ Email: bandika.civilunitri@gmail.com
}

\begin{abstract}
ABSTRAK
Indonesia memiliki lebih dari 80 ribu desa sebagai satuan administrasi terkecil dari NKRI. Setiap desa, setidaknya membutuhkan tiga hingga empat jembatan untuk menyeberangi sungai, dan untuk mengakses fasilitas lainnya. Kebutuhan jembatan yang banyak tersebut tidak dibarengi dengan anggaran negara yang dialokasikan terhadap pembangunan jembatan di desa-desa. Salah satu alternative konstruksi jembatan adalah dari material kayu juga merupakan material yang terbaharukan. Kendala dalam penggunaan kayu untuk konstruksi bangunan adalah kelangkaan kayu dengan dimensi besar. Untuk menanggulangi masalah tersebut, maka dibuatlah kayu rekayasa (engeenered wood), salah satunya yaitu box beam. Box beam terbukti dapat meningkatkan inersia suatu bahan jika dibandingkan balok kayu konvensional dengan luas penampang sama. Penelitian ini bertujuan untuk mencari perbandingan kekakuan antara jembatan kayu konvensional dan jembatan kayu menggunakan elemen box beam dari Kayu Kamper. Unsur kekakuan bisa dinilai dari besarnya lendutan yang terjadi. Hasil dari penelitian ini menunjukkan bahwa dari perbandingan box beam dan balok kayu biasa ternyata box beam menghasilkan lendutan untuk B.58.58.8 lendutannya $0.852 \mathrm{~mm}$. Untuk balok B.50.50.10 lendutan yang terjadi $0.894 \mathrm{~mm}$. Untuk balok B.45.45.12 lendutan yang terjadi $0.931 \mathrm{~mm}$. Sedangkan untuk balok control B.40.40.20 lendutan yang terjadi $0.950 \mathrm{~mm}$. Berdasarkan hasil penelitian dapat ditarik kesimpulan bahwa box beam memiliki lendutan yang lebih kecil dari pada jembatan rangka dengan balok control (konvensional). Dan bisa menjadi rekomendasi pemilihan tipe struktur jembatan bentang pendek untuk Pedesaan karena lebih kaku.
\end{abstract}

Kata kunci : jembatan rangka kayu; lendutan; box-beam section

\begin{abstract}
Indonesia has more than 80 thousand villages as the smallest administrative unit of the NKRI. Every village requires at least three to four bridges to cross the river, and to access other facilities. The need for many bridges is not accompanied by the state budget allocated for the construction of bridges in villages. One alternative to the bridge construction is from wood material which is also a renewable material. The obstacle in using wood for building construction is the scarcity of wood with large dimensions. To overcome this problem, the engineered wood emerged, one of which was the box beam. Box beam is proven to increase the inertia of a material compared to conventional wood beams with the same cross-sectional area. This study aims to find stiffness comparisons between conventional wooden bridges and wooden bridges using box beam elements from Camphor Wood. Stiffness can be assessed from the amount of deflection that occurs. The results of this study indicate that from the comparison of box beams and ordinary wooden beam, it turns out that the box beam produces deflection for B.58.58.8 is $0.852 \mathrm{~mm}$. For beam B.50.50.10 deflection that occurs $0.894 \mathrm{~mm}$. For beam B.45.45.12 deflection that occurs $0.931 \mathrm{~mm}$. Whereas for control beam B.40.40.20 deflection occurred $0.950 \mathrm{~mm}$. Based on the results of the study it can be concluded that the box beam has a deflection that is smaller than the frame bridge with the control beam (conventional). And it could be a recommendation for the selection of short span bridge structure types for $\mathrm{R}$ ural areas because they are more rigid.
\end{abstract}

Keywords: wood frame bridge; deflection; box-beam section 


\section{PENDAHULUAN}

Indonesia memiliki lebih dari 80 ribu desa sebagai satuan administrasi terkecil dari NKRI. Setiap desa, setidaknya membutuhkan tiga hingga empat jembatan untuk menyeberangi sungai, dan untuk mengakses fasilitas lainnya. Kepala Badan Penelitian dan Pengembangan (Balitbang) Kementrian Pekerjaan Umum dan Perumahan Rakyat tahun 2015 yaitu Waskito Pandu menyatakan bahwa kebutuhan jembatan sangat besar karena masyarakat memerlukan prasarana yang seringnya tidak tersedia di daerahnya, misalnya sekolah dan puskesmas [1].

Kebutuhan jembatan yang banyak tersebut tidak dibarengi dengan anggaran negara yang dialokasikan terhadap pembangunan jembatan di desa-desa. Karena pembangunan jembatan membutuhkan biaya yang relatif mahal. Teknologi terkini dari Kementrian Pekerjaan Umum dan Perumahan Rakyat dalam membangun jembatan di desa adalah teknologi "Judesa" yaitu kependekan dari Jembatan untuk DesaAsimetris. Material yang digunakan berasal dari bahan fabrikasi yang dikirim ke pelosokpelosok desa [2]. Teknologi Judesa telah dianggap sebagai jembatan yang ekonomis padahal anggaran yang dikeluarkan relatif besar yaitu 370 juta.

Pemilihan kayu sebagai material utama jembatan bukan tanpa alasan. Suryoatmono (2013) menyatakan bahwa sekarang ini persyaratan desain struktur selain harus memenuhi kekuatan dan daya layan tetapi juga harus memenuhi persyaratan ramah lingkungan dan hemat energi. Maka dari itu kayu adalah jawabannya. Kayu adalah material yang paling ramah lingkungan dibandingkan dengan material lain, yaitu beton dan baja. Berdasarkan laporan APA dalam Suryoatomo (2013), kebutuhan energi untuk menghasilkan 1 ton material semen, kaca, dan baja berturut-turut adalah 5 kali, 14 kali, dan 24 kali kebutuhan untuk menghasilkan 1 ton material kayu [3].

Kendala dalam penggunaan kayu untuk konstruksi bangunan adalah kelangkaan kayu dengan dimensi yang besar. Untuk menanggulangi masalah tersebut, maka muncullah balok kayu rekayasa (enginereed wood), salah satunnya adalah box-beam [4]. Penampang bollow terbukti dapat meningkatkan kegunaan material yaitu dapat meningkatkan besarnya inersia secara signifikan jika dibandingkan dengan kayu solid dengan luas penampang yang sama [5]. Bentuk penampang box beam dapat dilihat pada Gambar 1 di bawah ini.

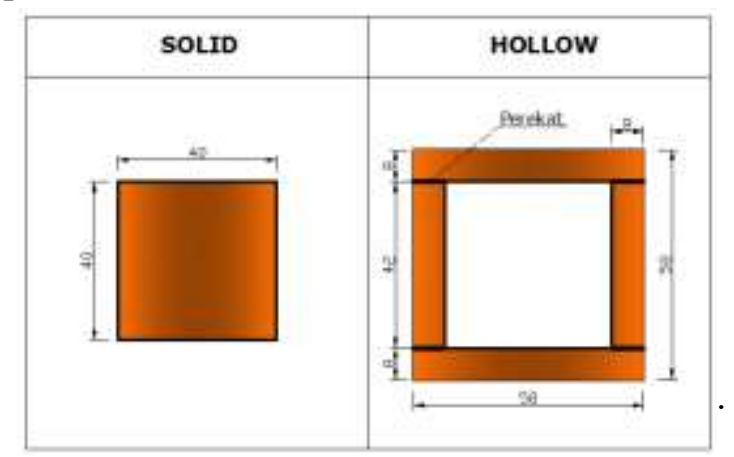

Gambar 1. Perbandingan penampang balok solid dan box beam dengan luas penampang sama (Sumber : Wijaya, 2014[6])

Kayu kamper (Dryoblanas sp.) adalah kayu yang digunakan dalam kebanyakan kontruksi bangunan. Kayu kamper tahan terhadap bubuk kayu, mempunyai kembang susut yang sedikit dan mudah diolah. Hal ini menjadikan kayu kamper banyak dipakai untuk bahan bangunan [7]. Modulus elastisitas kayu kamper pada kadar air 13,79\% yaitu 14783,58 $\mathrm{MPa}$ [8].

Berdasarkan kondisi tersebut maka penelitian ini bertujuan untuk mencari perbandingan kekuatan antara jembatan kayu konvensional dan jembatan kayu menggunakan elemen box beam dari Kayu Kamper. 


\section{METODE PENELITIAN}

\subsection{Karakteristik Kayu Kamper}

Jembatan box beam ini menggunakan material kayu kamper yang didukung data-data sifat-sifat fisik dan sifat mekanis yang dapat dilihat pada Tabel 1.

Tabel 1. Sifat fisik dan mekanik

\begin{tabular}{|c|c|}
\hline Nama Komersial & Kapur \\
\hline Warna kayu & $\begin{array}{l}\text { Kayu teras warna merah dan kayu gubal warna putih } \\
\text { sampai coklat kuning muda }\end{array}$ \\
\hline Tekstur & Agak kasar dan merata \\
\hline Kelas awet & II-III \\
\hline Kelas kuat & I-II \\
\hline Kembang susut & Sedang \\
\hline Berat jenis kering & $0.0008 \mathrm{~kg} / \mathrm{cm}^{3}$ \\
\hline Modulus elastisitas & $100.000 \mathrm{~kg} / \mathrm{cm}^{2}$ \\
\hline Kegunaan & Kayu bangunan, plywood kayu, lantai, papan, dll. \\
\hline
\end{tabular}

\subsection{Metode Analisis Jembatan Rangka Kayu}

Pada penelitian ini, analisis struktur rangka jembatan kayu akan dianalisis dengan menggunakan software Staad Pro 2004 yang merupakan software dengan pendekatan metode elemen hingga. Konfigurasi beberapa rangka yang dihitung adalah PRAT'T Truss yang dianalisis mulai dari input geometri struktur, pembebanan, dan tumpuannya yang akhirnya akan gaya-gaya aksial tarik dan tekan. Gaya aksial merupakan aspek dari kekuatan jembatan rangka kayu. Kekuatan tersebut akan dikawinkan dengan berat jembatan yang terdapat pada masing masing rangka. Rasio antara kekuatan dan berat jembatan yang terkecil yang merupakan indikator efisiensi penggunaan material sehingga akan tercipta konfigurasi struktur rangka jembatan yang kuat dan ekonomis.

\subsection{Pemodelan Struktur Jembatan Rangka}

Struktur jembatan rangka kayu ini merupakan permodelan struktur jembatan sebenarnya dikenai skala 1 : 10 yang dapat dilihat pada tabel 3 sebagai beikut:

Tabel 2. Data pemodelan struktur jembatan rangka

\begin{tabular}{cc}
\hline Bentang teoritis & 1.0 meter \\
\hline Tinggi jembatan & 0.25 meter \\
\hline Lantai jembatan & Jembatan rangka kayu dengan lantai kendaraan di \\
& bawah (Trough Type Truss) \\
\hline Lantai jembatan & Multipleks $3 \mathrm{~mm}$ \\
\hline Jumlah segmen & 4 segmen \\
\hline Tumpuan/ perletakan & Sendi dan rol \\
\hline Sambungan & Paku \\
\hline Material & Kayu Kamper \\
\hline
\end{tabular}




\subsection{Rancangan Penelitian}

Rancangan penelitian dari riset ini yaitu terdapat 4 variabel yaitu variable pertama yaitu Box beam dengan ukuran 58x58mm dengan tebal $8 \mathrm{~mm}$. Sedangkan variable kedua yaitu 40x40mm (Balok kontrol). Kedua variable tersebut memiliki persamaan yaitu luas penampang yang sama. Untuk lebih jelasnya dapat dilihat pada Tabel 3 berikut ini.

Tabel 3. Ukuran benda uji

\begin{tabular}{|c|c|c|c|c|}
\hline \multirow[t]{2}{*}{ Variasi } & \multicolumn{3}{|c|}{$\begin{array}{l}\text { Dimensi penampang } \\
\qquad(\mathrm{mm})\end{array}$} & \multirow{2}{*}{$\begin{array}{c}\text { Luas } \\
\text { penampang } \\
\left(\mathrm{mm}^{2}\right)\end{array}$} \\
\hline & b & h & $\mathbf{t}$ & \\
\hline B.58.58.8 & 58 & 58 & 8 & 1600 \\
\hline B.50.50.10 & 50 & 50 & 10 & 1600 \\
\hline B.45.45.12 & 45 & 45 & 12 & 1600 \\
\hline Balok Konvensional & 40 & 40 & 20 & 1600 \\
\hline
\end{tabular}

Untuk visualisasi masing-masing benda uji dapat dilihat pada Tabel 4 sebagai berikut :.

Tabel 4. Ukuran benda uji

\begin{tabular}{|c|c|c|}
\hline No & Dimensi Penampang & Keterangan \\
\hline 1 & 1 & $\begin{array}{l}\text { Jembatan tipe box beam dengan dimensi } 58 \mathrm{~mm} \\
\text { x } 58 \mathrm{~mm} \text { dengan tebal } 8 \mathrm{~mm} \text { (B.58.58.8) }\end{array}$ \\
\hline 2 & 4 & $\begin{array}{l}\text { Jembatan tipe box beam dengan dimensi } 50 \mathrm{~mm} \\
\text { x } 50 \mathrm{~mm} \text { dengan tebal } 10 \mathrm{~mm} \text { (B.50.50.10) }\end{array}$ \\
\hline 3 & & $\begin{array}{l}\text { Jembatan tipe box beam dengan dimensi } 45 \mathrm{~mm} \\
\text { x } 45 \mathrm{~mm} \text { dengan tebal } 12 \mathrm{~mm} \text { (B.45.45.12) }\end{array}$ \\
\hline 4 & & $\begin{array}{l}\text { Jembatan tipe balok konvensional dengan } \\
\text { dimensi } 40 \mathrm{~mm} \text { x } 40 \mathrm{~mm} \text { (B.K) }\end{array}$ \\
\hline
\end{tabular}




\subsection{Geometri Benda Uji}

Analisa struktur yang digunakan berbantuan software Staad Pro V8i. Hasil geometri jembatan rangka dapat dilihat pada Gambar 2.

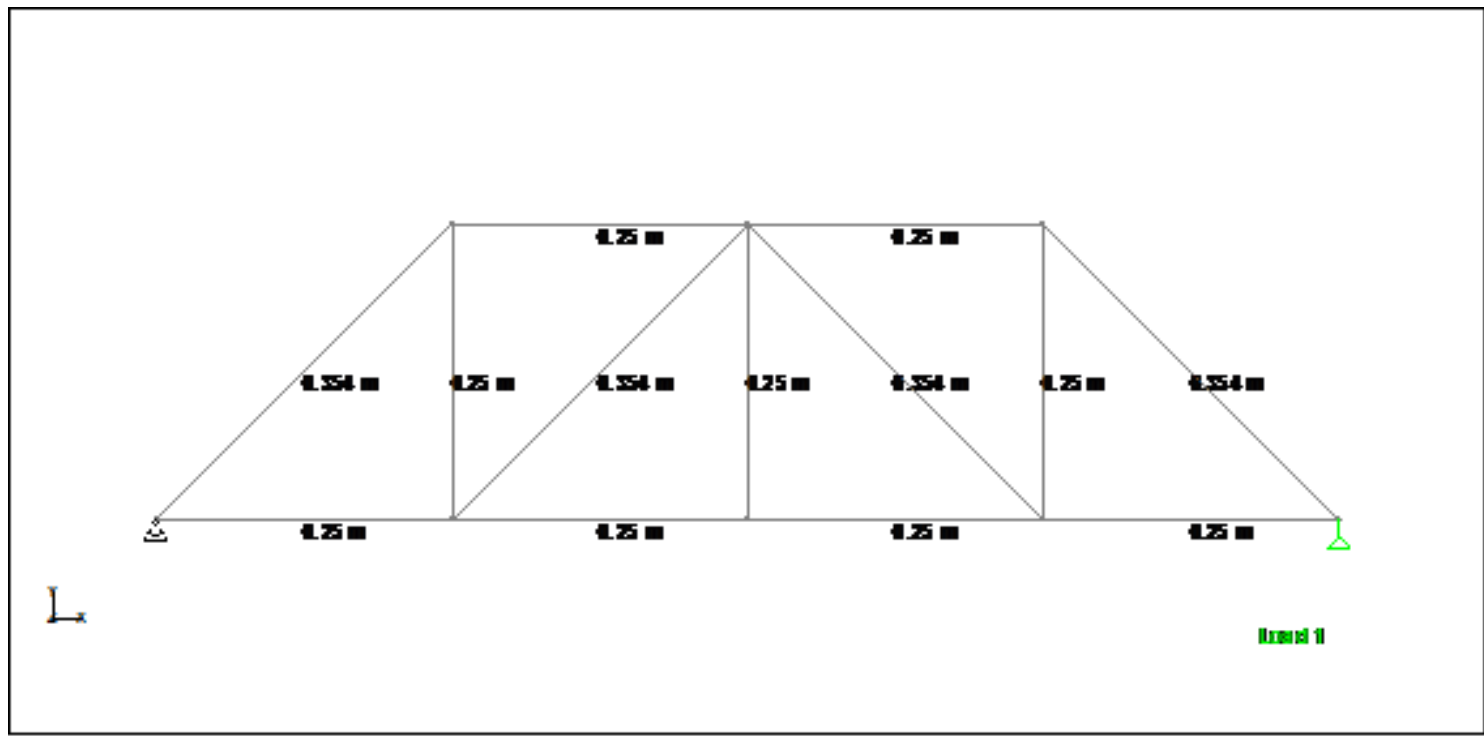

Gambar 2. Geometri Struktur Jembatan Rangka Kayu (Sumber : Software staad pro v8i)

Untuk memperjelas ukuran jembatan yang akan diuji dalam eksperimen masing-masing variasi dapat dilihat pada Gambar 3.

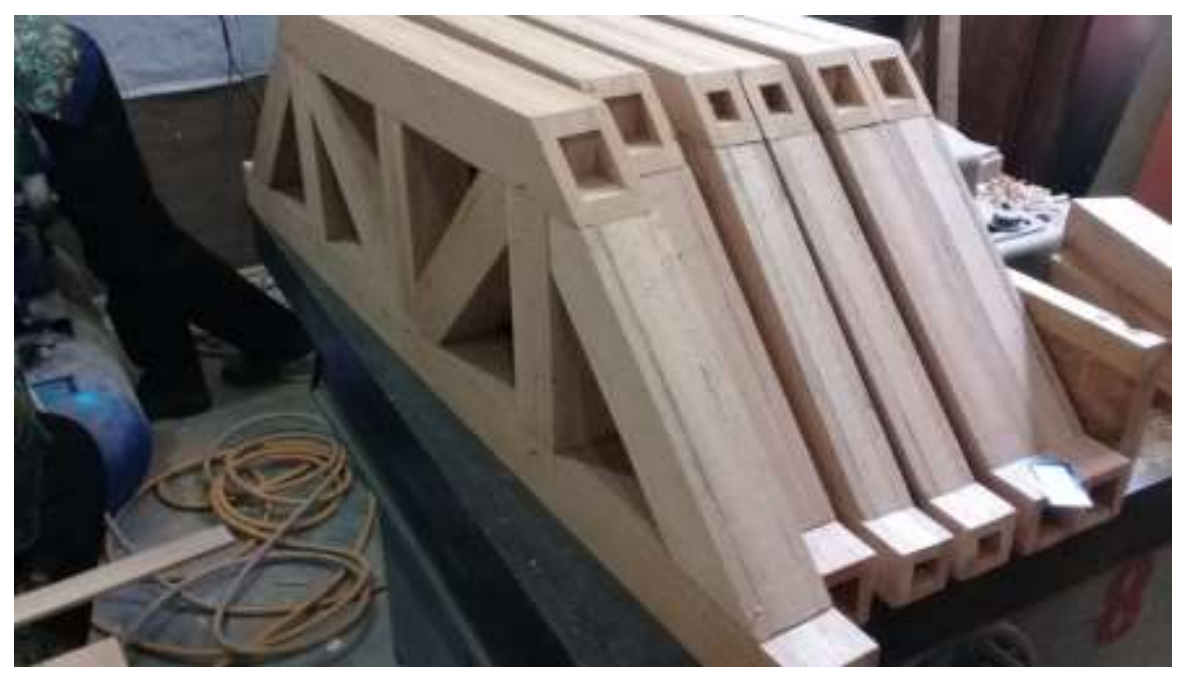

Gambar 3. Perbandingan Penampang Balok Solid dan Box Beam dengan Luas Penampang Sama (Sumber : dokumentasi eksperimen)

\subsection{Pembebanan Benda Uji}

Analisa pembebanan yang digunakan adalah beban $\mathrm{P}=1000 \mathrm{~kg}$ dikenakan di setengah bentang seperti pada Gambar 4. 


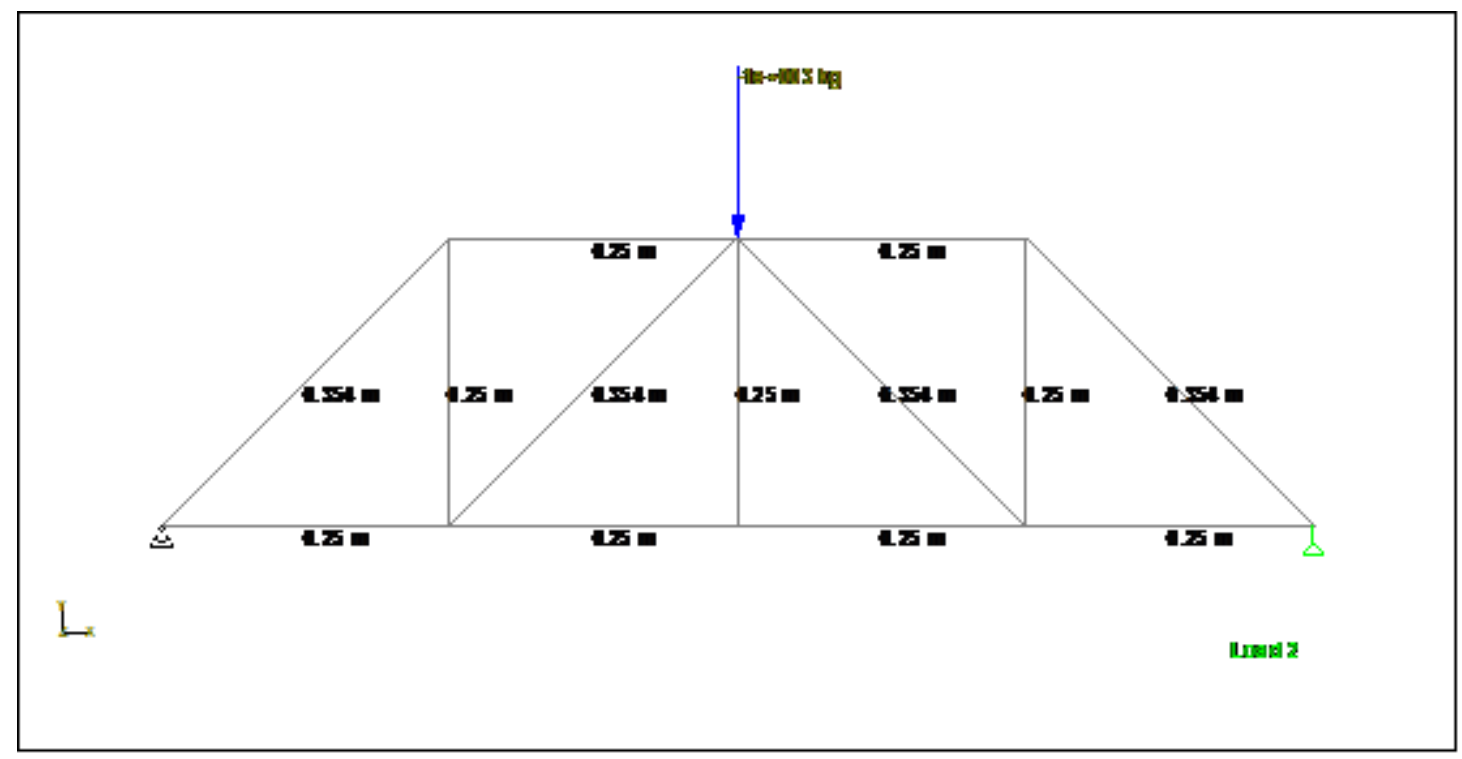

Gambar 4. Pembebanan struktur jembatan rangka kayu (Sumber : Softwere staad pro v8i)

Untuk memperjelas piranti pengujian dalam eksperimen ini dapat dilihat pada Gambar 5 berikut ini.

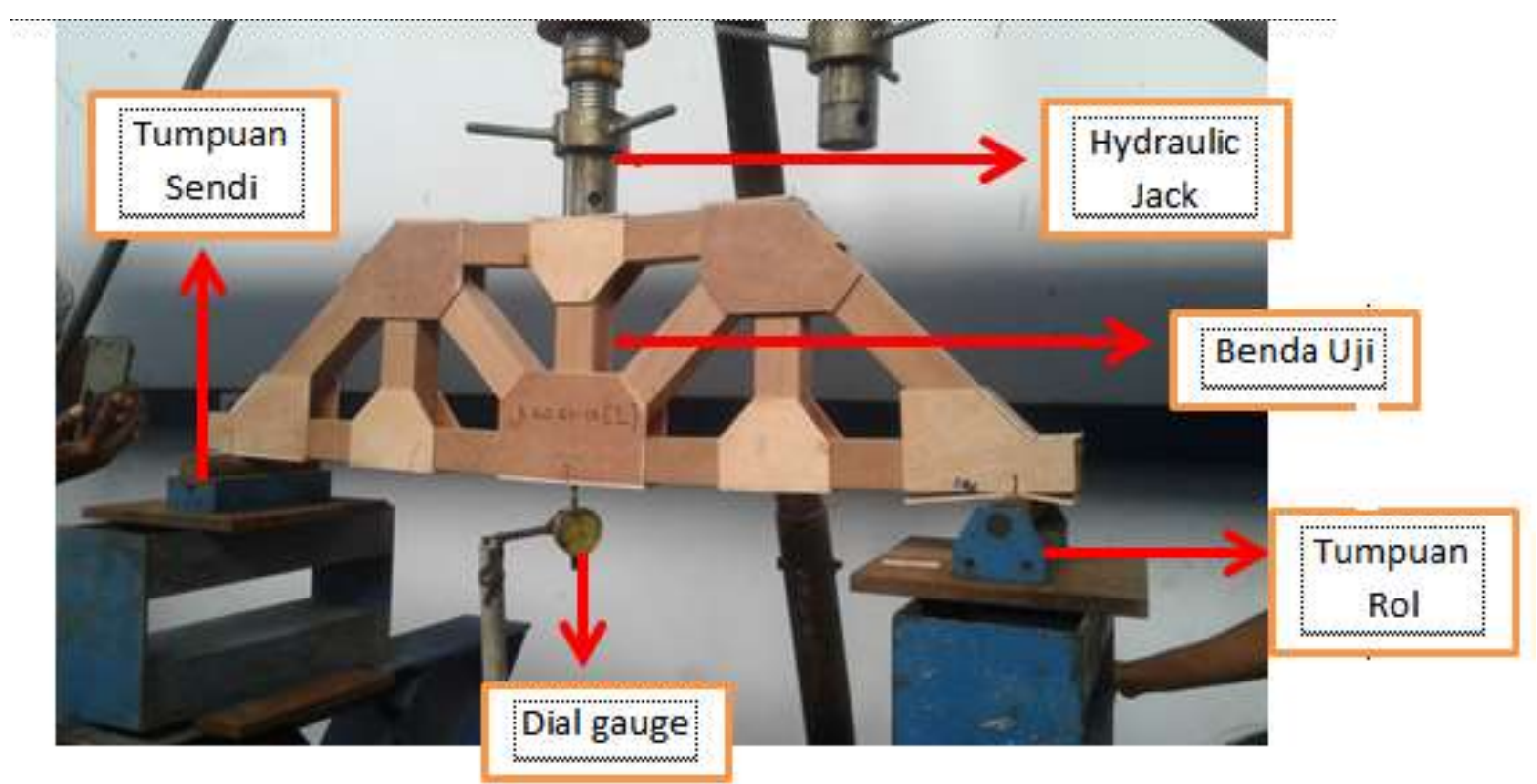

Gambar 5. Peralatan benda uji (Sumber : dokumentasi eksperimen)

\section{HASIL DAN PEMBAHASAN}

Indikator kekakuan dari penelitian ini adalah lendutan maksimal yang terjadi dengan beban 1000kg. Data lendutan maksimum masing-masing sampel dapat dilihat pada Gambar 6 - 9. 


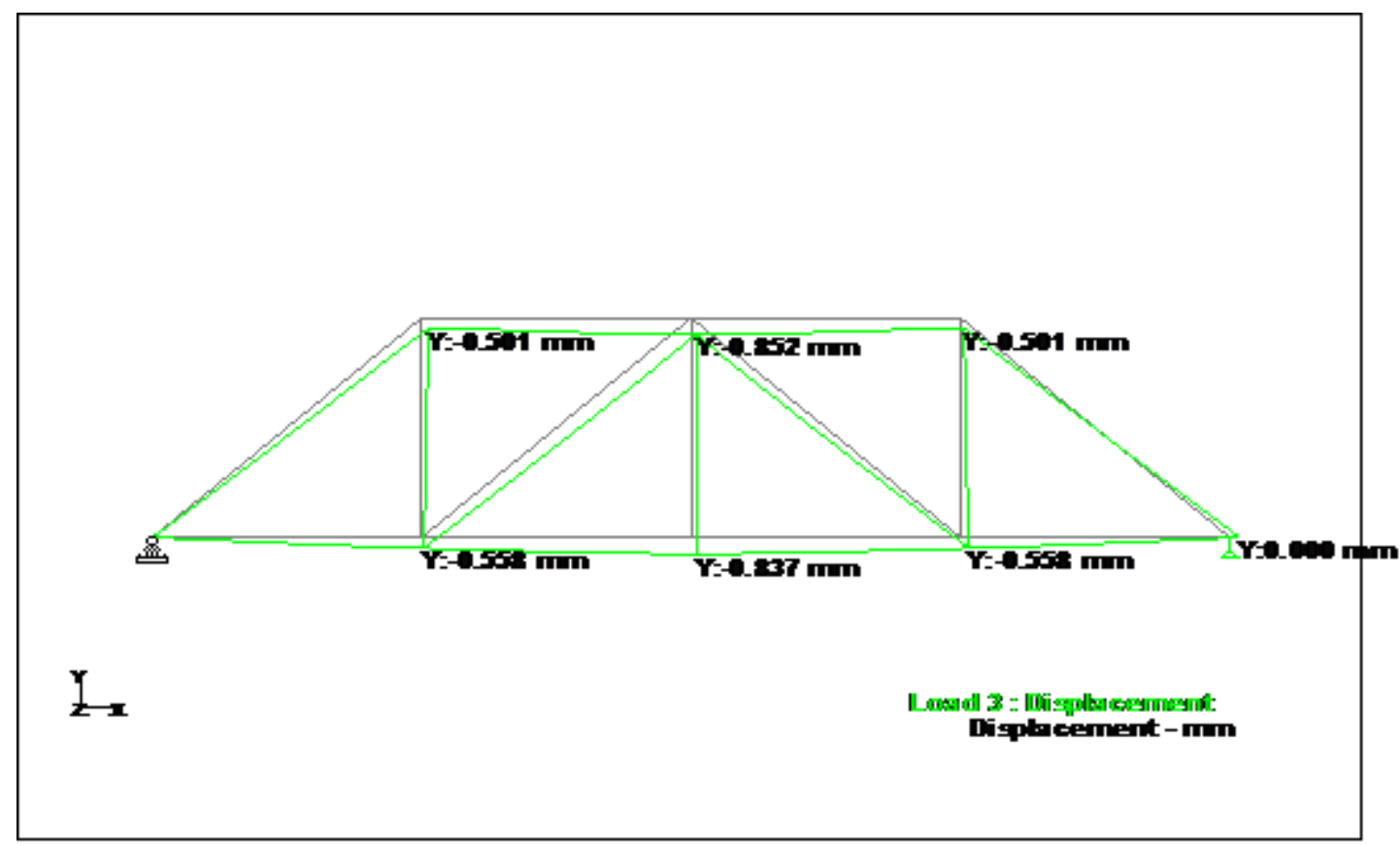

Gambar 6. Hasil lendutan untuk jembatan dengan box beam B.58.58.8 (Sumber : Software staad pro v8i)

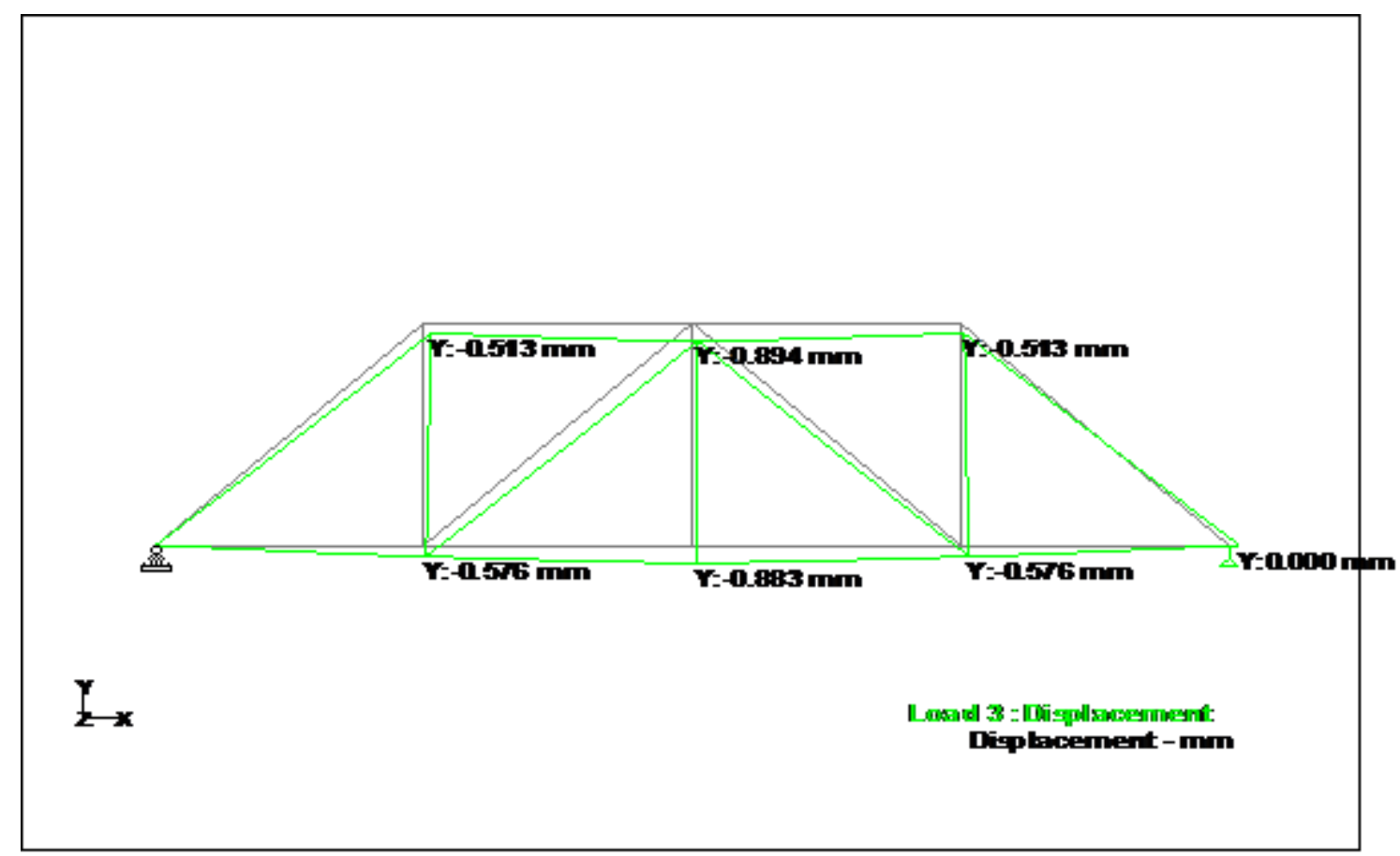

Gambar 7. Hasil lendutan untuk jembatan dengan box beam B.50.50.10 (Sumber : Software staad pro v8i) 


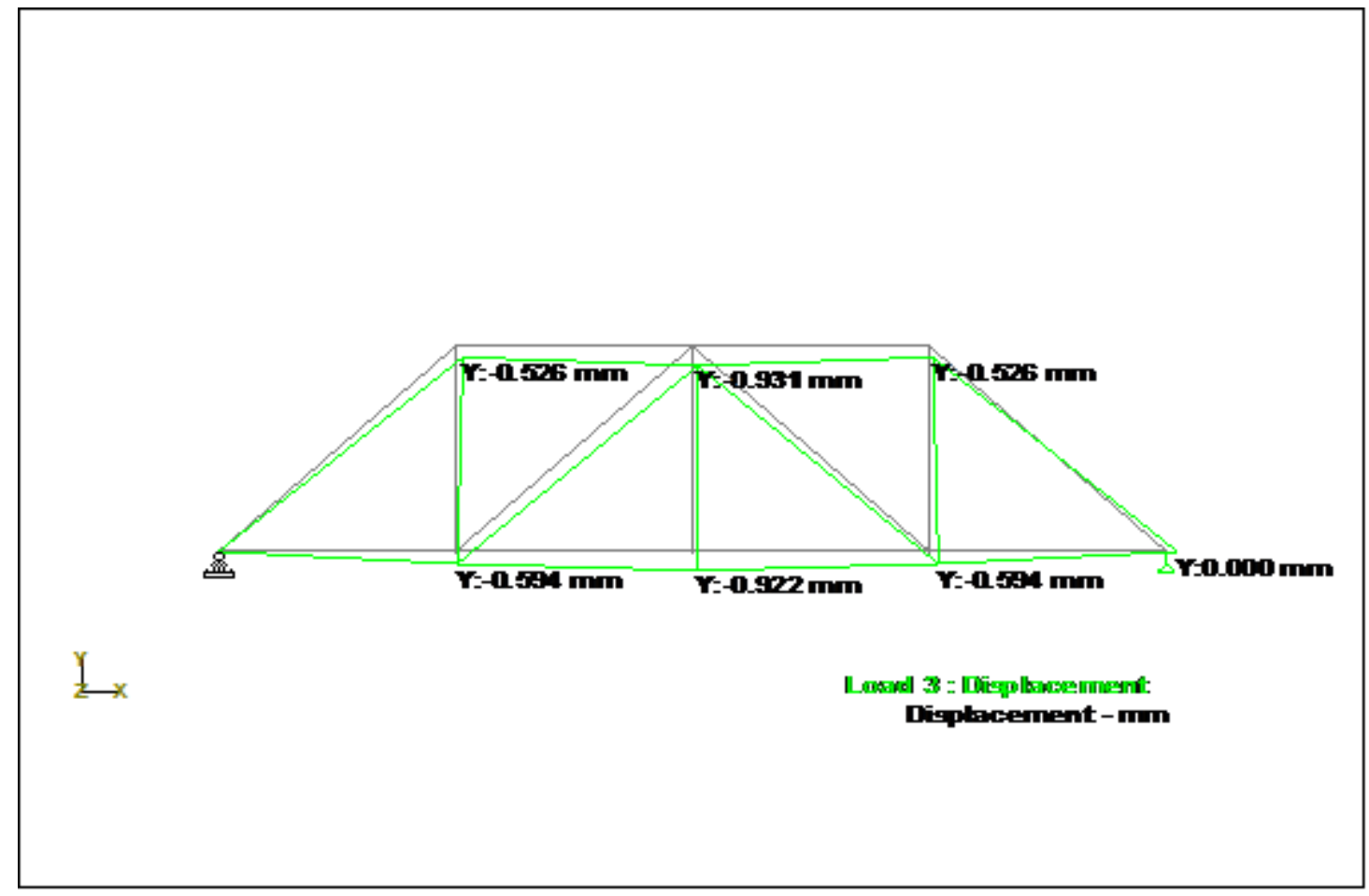

Gambar 8. Hasil lendutan untuk jembatan dengan box beam B.45.45.12

(Sumber : Software staad pro v8i)

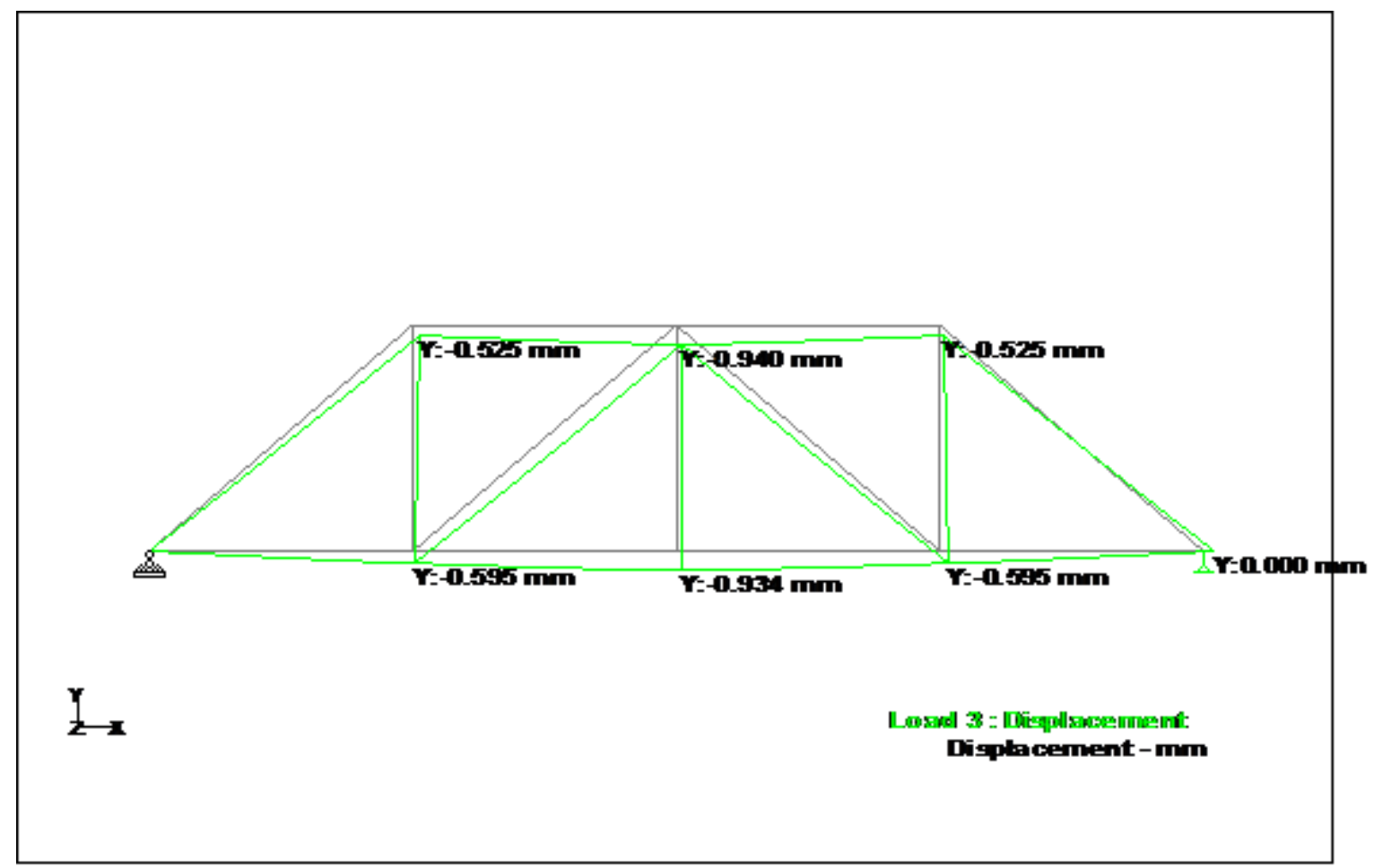

Gambar 9. Hasil lendutan untuk jembatan dengan balok kontrol B.40.40.20

(Sumber : Software staad pro v8i) 

Tabel 5 .

Untuk ringkasan lendutan maksimum yang terjadi masing-masing variasi dapat dilihat pada Tabel 5. Data lendutan kayu kamper hasil permodelan

\begin{tabular}{ccc}
\hline Vasiasi (a/t) & Luas $\left(\mathbf{m m}^{\mathbf{2}}\right)$ & $\begin{array}{c}\text { Lendutan maksimum } \\
(\mathbf{m m})\end{array}$ \\
\hline B.58.58.8 & 1600 & 0,852 \\
\hline B.50.50.10 & 1600 & 0,894 \\
\hline B.45.45.12 & 1600 & 0,931 \\
\hline Balok Konvensional & 1600 & 0,95 \\
\hline
\end{tabular}

Hasil dari penelitian ini menunjukkan bahwa dari perbandingan box beam dan balok kayu biasa ternyata box beam menghasilkan lendutan untuk B.58.58.8 lendutannya $0.852 \mathrm{~mm}$. Untuk balok B.50.50.10 lendutan yang terjadi $0.894 \mathrm{~mm}$. Untuk balok B.45.45.12 lendutan yang terjadi $0.931 \mathrm{~mm}$. Sedangkan untuk balok control B.40.40.20 lendutan yang terjadi $0.950 \mathrm{~mm}$. Untuk melihat secara jelas dapat divisualisasikan di Gambar 8 berikut.

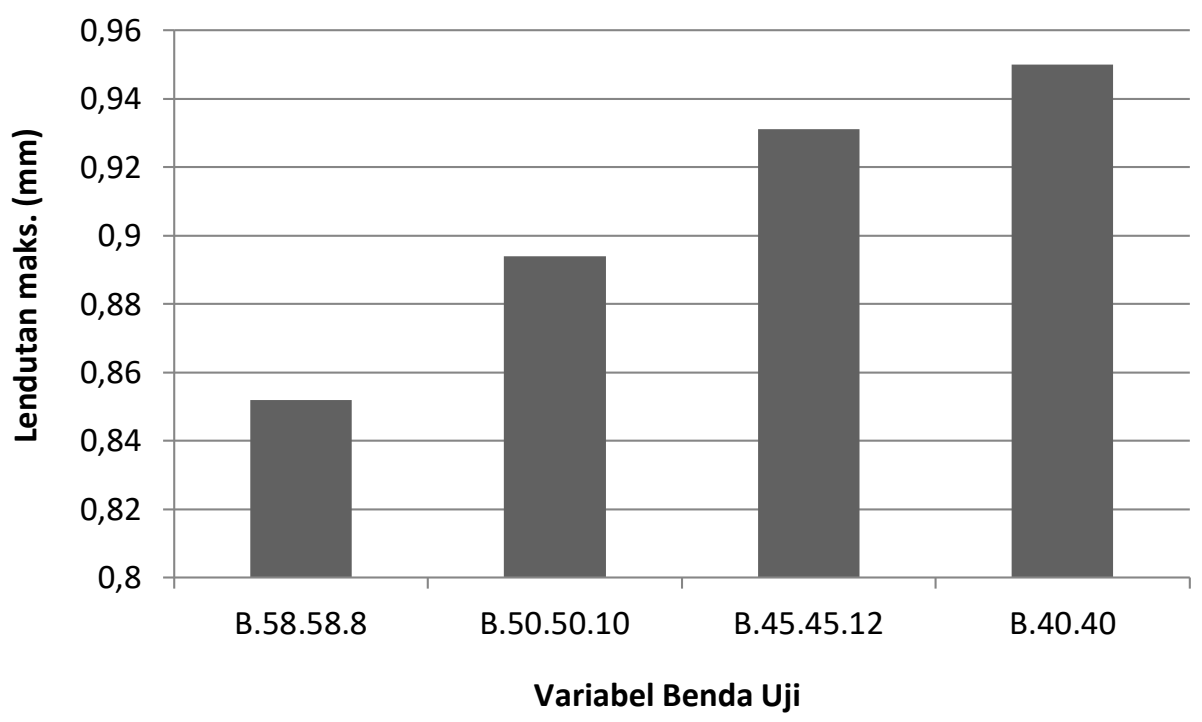

Gambar 10. Perbandingan lendutan maksimum antara box beam dan balok konvensional hasil analisa software Staad Pro

Dari Gambar 8 menunjukkan bahwa dengan adanya box beam tersebut, memberikan informasi penting bahwa box beam dapat memperbesar inersia suatu bahan sehingga kekakuan bahan semakin besar yang dibuktikan dengan lendutan pada jembatan box beam lebih kecil dari pada lendutan pada balok konvensional.

\section{KESIMPULAN}

Berdasarkan hasil penelitian dapat ditarik kesimpulan bahwa box beam memiliki lendutan yang lebih kecil dari pada jembatan rangka dengan balok kontrol (konvensional), dan bisa menjadi rekomendasi pemilihan tipe struktur jembatan bentang pendek untuk Pedesaan karena lebih kaku. 


\section{PENGHARGAAN}

Ucapan terimakasih diberikan kepada RISTEKDIKTI yang berperan besar dalam proses penelitian ini.

\section{DAFTAR PUSTAKA}

[1] Kementrian Pekerjaan Umum dan Perumahan Rakyat. (2015). Informasi Statistik Infrastruktur Pekerjaan Umum dan Perumahan Rakyat 2015. Jakarta : Kementrian Pekerjaan Umum dan Perumahan Rakyat.

[2] Kompas.com. (2015, 16 April). "Judesa" Cocok Dibangun di Desa Terpencil. Diperoleh 1 Juni 2017, dari

http://properti.kompas.com/read/ 2015/04/16/092900421/.Judesa.Co cok.Dibangun.di.Desa.Terpencil

[3] Suryoatmono, B. (2013) Kayu Rekayasa Sebagai Masa Depan Struktur Kayu Indonesia. Makalah disajikan dalam The 2nd Indonesian Structural Engineering And Materials Symposium, Jurusan Teknik Sipil Universitas Parahyangan, Bandung 7-8 November.

[4] Tjondro, Adhijoso. (2011) Balok Dan Kolom Papan Kayu Laminasi-
Paku. Bandung: Lembaga Penelitian

Dan Pengabdian Masyarakat Universitas Katolik Parahyangan.

[5] Karyadi, Sri Murni Dewi, Agoes Soehardjono Md. (2013) Experimental Investigation on Characteristics of Mechanics of Box-Section Beam Made Of SlicedLaminated Dendrocalamus Asper under Torsion. International Journal of Engineering Research and Applications (IJERA), 3 (4) : 2614-2619

[6] Wijaya, S. Handika. (2014). Kekuatan dan Kekakuan Puntir Balok Berpenampang Hollow (Box Beam) dari Kayu Kamper. Skripsi. Tidak dipublikasikan. Malang : Universitas Negeri Malang.

[7] Oka, Gusti Made. (2009) Analisis Rasio Antara Lebar Dan Tinggi Balok Terhadap Perilaku Lentur Kayu Kamper. Jurnal Smartek, 7 (1): $24-31$

[8] Putra, Dharma, Sugita, I N., NI Wayan P (2007) Tegangan Geser Ultimit Epoxy-Resin pada Sambungan Balok Kayu yang Dibebani Gaya Tekan Sejajar Serat. Jurnal Ilmiah Teknik Sipil. 11 (2): 165 -170 . 